\title{
Identification of superior cowpea varieties in competition with weeds ${ }^{1}$
}

\author{
Identificação de variedades superiores de feijão-caupi em competição com \\ plantas daninhas
}

\author{
Isis Fernanda Silva Medeiros ${ }^{2 *}$, Paulo Sérgio Lima e Silva ${ }^{2}$, Roberto Pequeno de Sousa ${ }^{2}$, Patrícia Liany de \\ Oliveira Fernandes Siqueira ${ }^{2}$ and Vianney Reinaldo de Oliveira ${ }^{2}$
}

\begin{abstract}
Cowpea varieties that are more competitive against weeds are, by themselves, not enough to control the weeds. However, the adoption of more-competitive varieties, together with other cropping practices, including planting density and weeding, can provide greater weed control in addition to affording the farmer more time to carry out this control. This study had the following objectives: a) to identify, in a preliminary evaluation (E-1), varieties that are the most competitive against weeds, based on dry grain yield; b) among the most-competitive varieties, identify the most productive in terms of green and dry grain yield (E-2). The seeds used for E-1 were obtained from producers chosen at random from each of 48 districts in the State of Rio Grande do Norte. A randomized block design with five replications was used. In E-2, the twelve varieties presenting the highest grain yield in E-1 were evaluated in a randomized block design with five replications. In both evaluations, only one weeding was carried out, 30 days after sowing. In E-1, the Umarizal, Itaú, Upanema, Lagoa de Pedras, José da Penha and São Tomé varieties were superior. The second experiment demonstrated that Umarizal is the most productive variety in terms of pod yield and green grain. There is no difference between the varieties for dry grain yield. The Umarizal variety has potential for use in the production of green pods and grains, and of dry grains. The preliminary evaluation is effective in identifying superior varieties.
\end{abstract}

Key words: Vigna unguiculata. Landraces. Immature grain. Ripe grain. Macassar beans.

\begin{abstract}
RESUMO - Variedades de feijão-caupi mais competitivas com plantas daninhas, isoladamente, não serão suficientes para controlar plantas daninhas. Entretanto, a adoção de variedades mais competitivas, juntamente com outras práticas culturais, incluindo densidade de plantio e capinas, propiciará maior controle das plantas daninhas, além de permitir mais tempo ao agricultor para efetuar esse controle. Este trabalho teve os objetivos: a) identificar, em avaliação preliminar (E-1), variedades mais competitivas com plantas daninhas, com base no rendimento de grãos secos; b) dentre as variedades mais competitivas identificadas, distinguir as mais produtivas em termos dos rendimentos de grãos verdes e secos (E-2). As sementes utilizadas em E-1 foram obtidas de produtores, tomados aleatoriamente, em cada um de 48 municípios do Estado do Rio Grande do Norte. Utilizou-se o delineamento de blocos ao acaso com cinco repetições. Em E-2, foram avaliadas, no delineamento de blocos ao acaso com cinco repetições, as doze variedades que apresentaram os maiores rendimentos de grãos em E-1. Nas duas avaliações, uma só capina foi realizada, aos 30 dias após a semeadura. Em E-1, são superiores as variedades Umarizal, Itaú, Upanema, Lagoa de Pedras, José da Penha e São Tomé. O segundo experimento indicou que a variedade Umarizal é a mais produtiva em termos dos rendimentos de vagens e de grãos verdes. As variedades não diferem quanto ao rendimento de grãos secos. A variedade Umarizal possui potencial para ser utilizada para produção de vagens e grãos verdes e grãos secos. A avaliação preliminar é eficiente em discriminar variedades superiores.
\end{abstract}

Palavras-chave: Vigna unguiculata. Variedades tradicionais. Grãos imaturos. Grãos maduros. Feijão-macassar.

DOI: $10.5935 / 1806-6690.20210042$

Editor-in-Chief: Eng. Agrônomo Dra. Charline Zaratin Alves - charline.alves@ufms.br

*Author for correspondence

Received for publication on 26/02/2020; approved on 23/03/2021

'Parte da Tese de Doutorado do primeiro autor apresentada ao Programa de Pós-Graduação em Fitotecnia, Departamento de Ciências Agronômicas e Florestais, Universidade Federal Rural do Semi-Árido/UFERSA

${ }^{2}$ Departamento de Ciências Agronômicas e Florestais, Universidade Federal Rural do Semi-Árido/UFERSA, Mossoró-RN, Brasil, isisfernanda. sm@hotmail.com (ORCID ID 0000-0001-9205-0248), paulosergio@ufersa.edu.br (ORCID ID 0000-0002-4465-6517), rsousa@ufersa.edu.br (ORCID ID 0000-0002-9103-8981), patricialianyofs17@gmail.com (ORCID ID 0000-0002-8782-7048), vianney.reinaldo@hotmail.com (ORCID ID 0000-0002-3853-7247) 


\section{INTRODUCTION}

The Northeast of Brazil covers an area of $1,561,178 \mathrm{~km}^{2}(18.3 \%$ of the country). Of this area, $62 \%$ corresponds to the semi-arid region, with $56,760,780$ inhabitants (27.2\% of the total population) (BNB, 2018). The cowpea [Vigna unguiculata (L.) Walp.] is one of the most important crops in the semi-arid region, where it is grown as a subsistence crop in every municipality.

In the semi-arid region, weed management in the cowpea is by hoeing, which is arduous, time-consuming and expensive. Two weedings, each requiring the work of one man over ten days, would currently cost at least BRL 1,000.00 (MEKONNEN et al., 2017). This activity, made more difficult on rainy days, is often carried out by poor and undernourished people. The adoption of cowpea varieties with greater competitive ability against weeds can help reduce the work of the farmer and maintain higher yields.

The effect of crops on weeds is known as interference. Zystro et al. (2012), called these effects suppressive ability. Such effects should be distinguished from the effects of weeds on crops, which are known as crop responses, and are different between cultivars, i.e., a cultivar might be more or less tolerant to weeds. As such, the competitiveness of a cultivar comprises two components: suppressive ability and tolerance (ZYSTRO et al., 2012). Increasing the competitive ability of the cowpea in the semi-arid region of Brazil is of great interest.

Increasing the competitiveness of cowpea varieties alone will not be enough to control the weeds. However, the adoption of more-competitive varieties together with other cropping practices, including planting density and weeding, can provide greater weed control, in addition to affording the farmer more time to carry out this control. This has been verified for several crops in various countries (ALI et al., 2017; BAJWA; WALSH; CHAUAN, 2017; DASS et al., 2017; JHA et al., 2017).

In general, genetic improvement reduces competitiveness because selection is often carried out together with good weed control, sometimes with the use of herbicides (ZHAI et al., 2016). However, there are differences in the competitive ability of corn hybrids (CARVALHO et al., 2011), showing that even among improved material, it is possible to find materials with greater competitive ability against weeds. In the cowpea, differences have been found between varieties against Alectra vogelii, and between cultivars against Striga gesnerioides, two required parasitic species (SALIFOU et al., 2017).

Traditional varieties are grown over several generations, often without efficient weed control, which favors the selection of more competitive types. Vandeleur and Gill (2004) found that traditional varieties of wheat not only gave greater weed suppression but were also more tolerant to the weeds.

The aims of this study were a) to identify, in a preliminary evaluation based on grain yield, traditional varieties that are more competitive against weeds; and b) among the most competitive varieties, identify the most productive in terms of green grain and dry grain yield.

\section{MATERIAL AND METHODS}

Two experiments were carried out at different times but in the same area: a preliminary selection of traditional cowpea varieties for competitiveness against weeds (experiment-1), and an additional evaluation of the varieties that proved to be superior in the preliminary evaluation (experiment-2).

\section{Methodology common to both experiments}

The experiments were carried out on the Rafael Fernandes Experimental Farm of the Federal Rural University of the Semi-Arid(UFERSA), located $20 \mathrm{~km}$ from the capital of the district of Mossoró, Rio Grande do Norte $(\mathrm{RN})\left(5^{\circ} 11^{\prime} \mathrm{S}, 37^{\circ} 20^{\prime} \mathrm{W}\right.$, at an altitude of $\left.18 \mathrm{~m}\right)$. The soil in the experimental area is classified as a Red Yellow Argisol (PVA), according to the Brazilian System of Soil Classification (SANTOS et al., 2018). The results of the analysis of a soil sample from each experiment are shown in Table 1.

According to the Köppen classification (1948), the climate in the region is type BSwh', i.e., very dry, with a mean annual rainfall of $825 \mathrm{~mm}$ and greater rainfall during the summer. The experiments were irrigated by sprinkler, with the experimental plots parallel to the lines of sprinklers. The amount of water needed was calculated considering the effective depth of the root system to be $40 \mathrm{~cm}$. Irrigation was carried out every two days and was based on the amount of water retained in the soil at a pressure of $0.40 \mathrm{Mpa}$. Irrigation began after sowing and was suspended 15 days after the first dry-pod harvest.

The soil was prepared by cross harrowing. The cowpea received $10 \mathrm{~kg}$ of $\mathrm{N}, 80 \mathrm{~kg}$ of $\mathrm{P}_{2} \mathrm{O}_{5}$ and $40 \mathrm{~kg}$ of $\mathrm{K}_{2} \mathrm{O}$ per hectare as fertilizer when planting. The fertilizers were applied manually in furrows below and to the side of the seeds. The experiments were sown on December 5, 2014, and October 29, 2015, respectively. Four seeds were sown per hole, and the plants thinned out 20 days after sowing, leaving the two largest plants in each hole. Thirty days after sowing, $10 \mathrm{~kg}$ of $\mathrm{N} \mathrm{ha}^{-1}$ were applied as top dressing. The sources of nitrogen, phosphorus and potassium were ammonium sulfate, single superphosphate and potassium chloride, respectively. 
Table 1 - Results of the chemical analysis of the soil from two experiments used to evaluate traditional varieties of cowpea for competitiveness against weeds. Mossoró, RN, 2018

\begin{tabular}{lcc}
\hline \multirow{2}{*}{ Characteristic } & \multicolumn{2}{c}{ Evaluation } \\
\cline { 2 - 3 } pH in water & Preliminary (experiment-1) & Additional (experiment-2) \\
Phosphorus $\left(\mathrm{mg} \mathrm{dm}^{-3}\right)$ & 7.00 & 7.60 \\
Poassium $\left(\mathrm{mg} \mathrm{dm}^{-3}\right)$ & 9.50 & 56.70 \\
Sodium $\left(\mathrm{mg} \mathrm{dm}^{-3}\right)$ & 110.40 & 71.20 \\
Calcium $\left(\mathrm{cmol}_{\mathrm{c}} \mathrm{dm}^{-3}\right)$ & 10.40 & 2.10 \\
Magnesium $\left(\mathrm{cmol}_{\mathrm{c}} \mathrm{dm}^{-3}\right)$ & 3.20 & 0.60 \\
Exchangeable acidity $\left(\mathrm{cmol}_{\mathrm{c}} \mathrm{dm}^{-3}\right)$ & 2.20 & 0.00 \\
Potential acidity $\left(\mathrm{cmol}_{\mathrm{c}} \mathrm{dm}^{-3}\right)$ & 0.00 & 0.00 \\
Sum of bases $\left(\mathrm{cmol}_{\mathrm{c}} \mathrm{dm}^{-3}\right)$ & 0.08 & 3.15 \\
Cation exchange capacity $\left(\mathrm{cmol}_{\mathrm{c}} \mathrm{dm}^{-3}\right)$ & 5.73 & 3.15 \\
Cation exchange capacity $(\mathrm{pH}=7)\left(\mathrm{cmol}_{\mathrm{c}} \mathrm{dm}^{-3}\right)$ & 5.73 & 3.15 \\
Base saturation $(\%)$ & 5.81 & 100.00 \\
Aluminum saturation $(\%)$ & 99.00 & 0.00 \\
Exchangeable sodium percentage $(\%)$ & 0.00 & 10.00 \\
\hline
\end{tabular}

In both experiments, chlorantraniliprole, bifenthrin and methomyl as active principles were applied using a backpack sprayer, with the aim of controlling the black cutworm (Agrotis ipsilon Hufnagel) and cowpea aphid (Aphis craccivora Kock).

To determine shoot dry weight in the cowpea, the plants from one hole were cut close to the ground and crushed in a forage cutter. A sample of approximately $100 \mathrm{~g}$ was then dried in a forced air circulation oven at $70{ }^{\circ} \mathrm{C}$ to constant weight.

The incidence of weeds in the experimental area was evaluated after the final bean harvest. The weeds were cut close to the ground, identified and weighed. A procedure similar to that adopted to determine dry matter in the cowpea, was used to estimate shoot dry matter in the weeds.

The data were subjected to analysis of variance using the SISVAR v5.3 software developed by the Federal University of Lavras (FERREIRA, 2010). Prior to the analysis of variance, the data were subjected to Bartlett's test for homogeneity of variances (NOGUEIRA; PEREIRA, 2013).

\section{Experiment-1}

The seeds used in experiment-1 were obtained from one producer chosen at random from each of the districts in the State of Rio Grande do Norte listed in Table 6 . The varieties were identified according to the name of the district where they were collected. When collecting the seeds, a brief interview was held with each producer with the aim of guaranteeing that the seeds came from a traditional variety.

A randomized block design was used with five replications, where the treatments corresponded to the 48 traditional varieties mentioned above. The varieties were weeded once, 30 days after sowing; it was considered that this procedure would cause moderate competitive stress against weeds in each variety, considering that, in this region, the cowpea is generally weeded twice (approximately 20 and 40 days after sowing).

The plots consisted of one row, $6.0 \mathrm{~m}$ in length, containing ten holes (each of two plants). The spacing between rows was $1.0 \mathrm{~m}$, with $0.6 \mathrm{~m}$ between holes in the same row. The plants in the holes at each end of the rows were considered borders. The plants in each row grown to the side of each block with the same variety of cowpea were also considered borders.

At flowering, the plants from one hole in each row were cut close to the ground and evaluated for length of the main branch, the number of secondary branches, the number of leaves, and the fresh and dry weight of the plant. The remaining plants in each plot were used to evaluate the dry grain yield. The pods were collected 95, 97 and 100 days after sowing, left in the sun to dry, and threshed manually. 
To evaluate dry matter in the above-ground part of the weeds, plants were collected from two randomly chosen areas of $0.6 \mathrm{~m}^{2}$ in each block.

The mean values were compared at 5\% probability using the Scott-Knott test (1974) whenever the value for the F-test in the analysis of variance was significant.

\section{Experiment-2}

In experiment-2, the 12 varieties that presented the highest grain yields in the preliminary evaluation for competitiveness against weeds were evaluated in a randomized block design with five replications (Umarizal, Itaú, Upanema, Lagoa de Pedra, José da Penha, São Tomé, Baraúna, Campo Grande, Luiz Gomes, Angicos, Jaçanã and Macaíba). These varieties were subjected to moderate weed stress by being weeded once, 30 days after sowing.

Each plot consisted of four rows, $6.0 \mathrm{~m}$ in length, with the area occupied by the two central rows considered the working area; the plants from one hole at each end of the two central rows were disregarded in all the evaluations. One of the rows of the working area was used to evaluate green grain yield and the other to evaluate dry grain yield. A spacing of $1.0 \mathrm{~m} \times 1.0 \mathrm{~m}$ was used, with two plants per hole. As such, eight plants were used to evaluate the green grain and dry grain yield.

Green bean yield was determined from the weight of the pods and grain, collected in ten harvests from 53 to 82 days after sowing. The green grain yield was corrected for a moisture content of $65 \%$ (mean value of the grain moisture content of each variety). Also evaluated were the number of pods plant ${ }^{-1}$, the number of beans $\operatorname{pod}^{-1}$ (in 10 pods), the 100-grain weight (in five samples), and the length, width, and thickness of 10 pods and 10 grains. The dry grain yield was determined from the dry grain weight, collected in four harvests from 70 to 82 days after sowing. In addition to yield (corrected for a moisture content of $15.5 \%$.), the following were evaluated: the number of pods plant ${ }^{-1}$; the number of beans pod ${ }^{-1}$ (in 10 pods); the 100-grain weight (in five samples); and the length, width and thickness of 10 grains. After the final harvest of dry grains, the plants from a randomly chosen hole were cut close to the ground, weighed and ground. A sample of the ground material, weighing approximately $100 \mathrm{~g}$, was placed in a forced air circulation oven at $70{ }^{\circ} \mathrm{C}$ to constant weight. This made it possible to estimate shoot dry weight in the cowpea.

Ninety-one days after sowing, the weeds from an area of $1.0 \mathrm{~m}^{2}$ in each plot were collected to determine the weight of the shoots.

The mean values of the treatments were compared using Tukey's test (BRAUN, 1994), at 5\% probability.

\section{RESULTS AND DISCUSSION}

\section{Weeds}

\section{Experiment-1}

The weed species occurring during experiment-1 were: Adenocalymma sp. (80), Alternanthera tenella Colla (40), Borreria verticillata L. (40), Cenchrus echinatus L. (100), Commelina benghalensis L. (20), Dactyloctenium aegyptium (L.) Willd. (20), Digitaria sp. (100), Panicum maximum Jacq. (20) and Turnera subulata Sm. (40). The numbers in parentheses indicate the percentage rate of occurrence, i.e., the ratio between the number of plots in which a particular species occurred and the total number of plots. The most frequent species, i.e., Adenocalymma sp., Cenchrus echinatus L. and Digitaria sp. are considered difficult to control (ARRUDA et al., 2015; PEREIRA et al., 2015).

\section{Experiment-2}

Table 2 shows the list of weed species that occurred during the experiment after the final bean harvest. The most frequent species were Cenchrus equinatus, Dactyloctenium aegyptium and Digitaria sp. Yadav et al. (2017), related the weed species that generally occur in the cowpea to genotypic and environmental factors. Genotypic factors include the variety of cowpea, weed species and biotic agents (fauna). Among the environmental factors can be included variations in soil and climate that, although relatively small, occur in the experimental environment (blocks and plots). The distribution of weed species in the experimental area was not uniform (Table 3). Weed species occur individually as aggregates; their distribution depends on the properties of the soil and is specific to each area (METCALFE et al., 2016).

There was no effect from the treatments on weed growth (Table 4), determined from the fresh and dry weight of the shoots. The fresh matter weight ranged from $923 \mathrm{~g} \mathrm{~m}^{-2}$ (weeds associated with the Luiz Gomes variety) to $1517 \mathrm{~g} \mathrm{~m}^{-2}$ (weeds associated with the Itaú variety). The experimental coefficient of variation (CV) was $38.9 \%$. The dry matter weight ranged from 130 to $267 \mathrm{~g} \mathrm{~m}^{-2}$ in weeds associated with the same cowpea varieties, and the $\mathrm{CV}$ was $36.7 \%$.

\section{Cowpea}

\section{Experiment-1}

Of the six characteristics used to evaluate growth in the cowpea, the treatments influenced the number of leaves only (not indicated by the F-test but revealed by Tukey's test) (Table 5). The varieties Itaú, José da Penha, Campo Grande, Alexandria, Pedro Velho, Monte Alegre, Pedra Preta, Felipe Guerra, Santana do Matos, Apodi, Senador Eloi de Souza, São José do Mipibu and São Gonçalo do Amarante did not differ from each other and were superior to the other varieties 
Table 2 - Occurrence index for weed species in experiment- $2 .{ }^{1}$

\begin{tabular}{|c|c|c|}
\hline Number & Species & Occurrence index $1 \%)$ \\
\hline 1 & Adenocalymma sp. & 13 \\
\hline 2 & Alternanthera tenella Colla & 8 \\
\hline 3 & Amaranthus viridis L. & 37 \\
\hline 4 & Borreria verticillata $\mathrm{L}$. & 2 \\
\hline 5 & Cenchrus echinatus L. & 100 \\
\hline 6 & Citrullus lanatus Thunb & 3 \\
\hline 7 & Commelina benghalensis L. & 48 \\
\hline 8 & Dactyloctenium aegyptium (L.) Willd. & 80 \\
\hline 9 & Digitaria sp. & 55 \\
\hline 10 & Euphorbia hyssopifolia L. & 23 \\
\hline 11 & Jacquemontia sp. & 10 \\
\hline 12 & Neojobertia candolleana (Mart. ex DC.) Bureau \& K. Schum & 2 \\
\hline 13 & Portulaca oleracea L. & 40 \\
\hline 14 & Turnera subulata $\mathrm{Sm}$. & 5 \\
\hline
\end{tabular}

${ }^{1}$ Occurrence index $=$ ratio between the number of plots in which a particular weed species occurred and the total number of experimental plots

Table 3 - Distribution of weed species in plots of traditional varieties of cowpea in experiment-2. The numbers correspond to the species identified in Table 2. Mossoró, RN, 2018

\begin{tabular}{lcccccc}
\hline \multirow{2}{*}{ Traditional variety } & \multicolumn{7}{c}{ Blocks } & \multicolumn{2}{c}{ Total species } \\
\cline { 2 - 6 } & 1 & 2 & 3 & 4 & 5 & 7 \\
\hline Umarizal & $3-5-9-13$ & $5-7-9-13$ & $5-7-8-9$ & $5-7-8-9$ & $3-5-7-8-9-10$ & 9 \\
Itaú & $1-3-5-6-11$ & $5-7-8-13$ & $5-7-8-9$ & $5-7-9$ & $5-8-9$ & 8 \\
Upanema & $5-6-7$ & $5-8-9-10-11-13$ & $5-8-9-13$ & $5-7-8-9$ & $5-7-8-9-10$ & 8 \\
Lagoa de Pedra & $5-8-13$ & $1-5-7-8-13$ & $3-5-9-10$ & $3-5-8-13$ & $3-5-8-10$ & 7 \\
José da Penha & $1-3-5-7-8-9-13$ & $1-5-7-8-13$ & $5-7-8-9-13$ & $3-5-7-8-9$ & $3-5-8-9$ & 9 \\
São Tomé & $2-5-7-9$ & $5-7-8-13$ & $3-5-8-9-10-11$ & $3-5-8$ & $5-8-10$ & 9 \\
Baraúna & $1-5-11$ & $1-3-5-8-11-13$ & $3-5-7-8-9-13$ & $5-8$ & $3-5-8-13-14$ & 7 \\
Campo Grande & $3-5-8-13$ & $1-5-8-9-13$ & $3-5-7-8$ & $3-5-7-9$ & $5-8-9-13$ & 7 \\
Luiz Gomes & $5-13$ & $5-7-8-13$ & $5-8-9-10$ & $5-9-10$ & $3-5-9$ & 12 \\
Angicos & $1-2-5-7-8-9-13$ & $2-5-8-10$ & $5-7-8-9$ & $3-4-5-8-12$ & $3-5-8-14$ & 9 \\
Jaçanã & $3-5-7-8-13$ & $2-5-7-8$ & $5-8-10-14$ & $5-8-10$ & $3-5-7-8-9$ & 9 \\
Macaíba & $5-7-8-9-13$ & $1-2-5-8-10-13$ & $5-7-8-9$ & $5-7-8-9$ & $5-8-9-10-11$ & \\
\hline
\end{tabular}

Table 4 - Summary of the analysis of variance for fresh and dry weight in weed shoots in a cultivation of cowpea varieties in experiment- $2 .{ }^{1}$

\begin{tabular}{|c|c|c|c|c|c|}
\hline \multirow{4}{*}{ Source of variation } & \multirow{4}{*}{ Degrees of freedom } & \multicolumn{4}{|c|}{ Mean Square } \\
\hline & & \multicolumn{4}{|c|}{ Shoot matter } \\
\hline & & \multicolumn{2}{|c|}{ Weeds $\left(\mathrm{g} \mathrm{m}^{-2}\right)$} & \multicolumn{2}{|c|}{ Cowpea $\left(\right.$ g plant $\left.^{-1}\right)$} \\
\hline & & Fresh & Dry & Fresh & Dry \\
\hline Blocks & 4 & $557,714.61 *$ & $4,865.78^{\mathrm{ns}}$ & $33,710.55^{\mathrm{ns}}$ & $1,129.35^{\mathrm{ns}}$ \\
\hline Varieties & 11 & $179,979.94^{\mathrm{ns}}$ & $6,529.28^{\mathrm{ns}}$ & $57,974.62^{\mathrm{ns}}$ & $1,346.83^{\mathrm{ns}}$ \\
\hline Residual & 44 & $189,860.37$ & $4,651.71$ & $42,728.85$ & $1,262.81$ \\
\hline
\end{tabular}

1 ns; *: not significant, and significant at $5 \%$ respectively by F-test 
in terms of the number of leaves per plant (Table 6). Despite the effect of the varieties on the number of leaves, which contributes to shoot matter, the varieties did not differ in terms of fresh or dry shoot matter. Shoot fresh matter per plant ranged from $41.4 \mathrm{~g}$ (Santa Cruz) to $72.4 \mathrm{~g}$ (Campo Grande), with a mean value of $53.4 \mathrm{~g}$ and $\mathrm{CV}$ of $36.0 \%$. Shoot dry matter per plant ranged from $4.9 \mathrm{~g}$ (Carnaúba dos Dantas and Lagoa Salgada) to $8.7 \mathrm{~g}$ (Campo Grande), with a mean value of $6.5 \mathrm{~g}$ and $\mathrm{CV}$ equal to $36.0 \%$. Differences in the weight of the leaves and branches (not evaluated in the present study) must have compensated for the differences seen in the number of leaves.

Table 5 - Summary of the analysis of variance for growth characteristics and grain yield in traditional varieties of cowpea initially evaluated for competitiveness against weeds (experiment- 1$){ }^{1}$

\begin{tabular}{lccccccccc}
\hline \multirow{2}{*}{$\begin{array}{l}\text { Source of } \\
\text { Variation }\end{array}$} & $\begin{array}{c}\text { Degrees of } \\
\text { freedom }\end{array}$ & $\begin{array}{l}\text { Total } \\
\text { fresh matter }(\mathrm{g})\end{array}$ & $\begin{array}{l}\text { Total plant } \\
\text { dry matter }(\mathrm{g})\end{array}$ & $\begin{array}{l}\text { Number } \\
\text { secondary branches }\end{array}$ & $\begin{array}{c}\text { Number of } \\
\text { leaves }\end{array}$ & $\begin{array}{c}\text { Length of the main } \\
\text { branch }(\mathrm{cm})\end{array}$ & $\begin{array}{c}\text { Dry } \\
\text { grain yield } \\
\left(\mathrm{kg} \mathrm{ha}^{-1}\right)\end{array}$ \\
\hline Blocks & 4 & $3,462.89^{* *}$ & $53.67^{* *}$ & $105.77^{* *}$ & $879.89^{* *}$ & $462.83^{* *}$ & $241,790.67^{* *}$ \\
Varieties & 47 & $383.01^{\text {ns }}$ & $4.43^{\text {ns }}$ & $12.19^{\text {ns }}$ & $120.50^{\text {ns }}$ & $27.77^{\text {ns }}$ & $295,797.54^{* *}$ \\
Residual & 188 & 368.71 & 4.21 & 9.93 & 87.58 & 23.73 & $51,851.59$ \\
\hline
\end{tabular}

1 ns; *; **: not significant, significant at $5 \%$, and significant at $1 \%$ respectively by F-test

Table 6 - Mean values for growth characteristics and grain yield in traditional varieties of cowpea evaluated in competition with weeds (experiment-1). ${ }^{1}$

\begin{tabular}{|c|c|c|c|c|c|}
\hline Variety & Number of leaves per plant & Grain yield $\left(\mathrm{kg} \mathrm{ha}^{-1}\right)$ & Variety & Number of leaves per plant & Grain yield $\left(\mathrm{kg} \mathrm{ha}^{-1}\right)$ \\
\hline Umarizal & $29.3 \mathrm{~b}$ & $945 \mathrm{a}$ & Ceará Mirim & $29.0 \mathrm{~b}$ & $329 \mathrm{c}$ \\
\hline Itaú & $39.0 \mathrm{a}$ & $937 \mathrm{a}$ & Carnaúba dos Dantas & $24.7 \mathrm{~b}$ & $320 \mathrm{c}$ \\
\hline Upanema & $28.7 \mathrm{~b}$ & $863 \mathrm{a}$ & Serrinha & $33.7 \mathrm{~b}$ & $319 \mathrm{c}$ \\
\hline Lagoa de Pedras & $28.9 \mathrm{~b}$ & $822 \mathrm{a}$ & Felipe Guerra & $42.0 \mathrm{a}$ & $303 \mathrm{c}$ \\
\hline José da Penha & $42.7 \mathrm{a}$ & $817 \mathrm{a}$ & Lagoa d'anta & $33.4 \mathrm{~b}$ & $293 \mathrm{c}$ \\
\hline São Tomé & $31.2 \mathrm{~b}$ & $765 \mathrm{a}$ & Lagoa Salgada & $25.3 \mathrm{~b}$ & $267 \mathrm{c}$ \\
\hline Baraúna & $29.6 \mathrm{~b}$ & $689 \mathrm{~b}$ & Boa Saúde & $32.4 \mathrm{~b}$ & $251 \mathrm{c}$ \\
\hline Campo Grande & $44.8 \mathrm{a}$ & $683 \mathrm{~b}$ & Nova Cruz & $31.0 \mathrm{~b}$ & $241 \mathrm{c}$ \\
\hline Luiz Gomes & $33.6 \mathrm{~b}$ & $668 \mathrm{~b}$ & Vera Cruz & $31.1 \mathrm{~b}$ & $241 \mathrm{c}$ \\
\hline Angicos & $32.7 \mathrm{~b}$ & $655 \mathrm{~b}$ & Santana do Matos & $41.3 \mathrm{a}$ & $239 c$ \\
\hline Jaçanã & $27.7 \mathrm{~b}$ & $649 \mathrm{~b}$ & Lajes & $29.9 \mathrm{~b}$ & $231 \mathrm{c}$ \\
\hline Macaíba & $30.6 \mathrm{~b}$ & $615 b$ & Tenente Ananias & $28.9 \mathrm{~b}$ & $229 \mathrm{c}$ \\
\hline Japi & $30.8 \mathrm{~b}$ & $612 b$ & Tangará & $28.1 \mathrm{~b}$ & $228 \mathrm{c}$ \\
\hline Tenente Laurentino Cruz & $34.2 \mathrm{~b}$ & $563 \mathrm{~b}$ & Apodi & $40.3 \mathrm{a}$ & $225 \mathrm{c}$ \\
\hline Carnaubais & $31.5 \mathrm{~b}$ & $562 \mathrm{~b}$ & São Bento do Trairi & $29.2 \mathrm{~b}$ & $225 \mathrm{c}$ \\
\hline Alexandria & $40.2 \mathrm{a}$ & $544 \mathrm{~b}$ & Currais Novos & $34.2 \mathrm{~b}$ & $223 \mathrm{c}$ \\
\hline Pedro Velho & $36.4 \mathrm{a}$ & $490 \mathrm{~b}$ & Senador Elói de Souza & $40.6 \mathrm{a}$ & $181 \mathrm{c}$ \\
\hline Monte Alegre & $39.4 \mathrm{a}$ & $450 \mathrm{c}$ & São José do Mipibu & $35.8 \mathrm{a}$ & $179 \mathrm{c}$ \\
\hline Pedra Preta & $37.3 \mathrm{a}$ & $449 \mathrm{c}$ & Mossoró & $34.1 \mathrm{~b}$ & $169 \mathrm{c}$ \\
\hline Passa e Fica & $27.3 \mathrm{~b}$ & $438 \mathrm{c}$ & Santa Cruz & $27.8 \mathrm{~b}$ & $150 \mathrm{c}$ \\
\hline Campo Redondo & $32.3 \mathrm{~b}$ & $375 \mathrm{c}$ & Serra do Mel & $25.6 \mathrm{~b}$ & $112 \mathrm{c}$ \\
\hline Bodó & $34.0 \mathrm{~b}$ & $368 \mathrm{c}$ & São Gonçalo do Amarante & $38.3 \mathrm{a}$ & $97 \mathrm{c}$ \\
\hline São José do Campestre & $32.1 \mathrm{~b}$ & $367 \mathrm{c}$ & São Miguel & $33.2 \mathrm{~b}$ & $63 \mathrm{c}$ \\
\hline São Paulo do Potengi & $34.0 \mathrm{~b}$ & $334 \mathrm{c}$ & Martins & $33.5 \mathrm{~b}$ & $57 \mathrm{c}$ \\
\hline \multicolumn{6}{|c|}{ Coefficient of variation for the number of leaves per plant: $28.2 \%$} \\
\hline Coefficient of variation $\mathrm{f}$ & grain yield: $55.1 \%$ & & & & \\
\hline
\end{tabular}


Similar results to those found in the present study regarding cowpea growth were seen by various authors who also demonstrated the effect of the variety $\mathrm{x}$ environment interaction on characteristics associated with growth(MFEKA; MULIDZI; LEWU, 2019). The fact that no effect from variety was detected on some of the component characteristics of vegetative growth may be related, at least in some cases, to experimental error. The loss of plant material with senescence, especially the leaves, can lead to experimental error; but even characteristics like the number of secondary branches and length of the main branch are subject to experimental error. As all the varieties under evaluation in the present study are of indeterminate growth, branches from the plants in each plot were not restricted to the areas of the plots in which they originated. As a result, during each harvest, branches were broken, and material was lost.

It is important to remember that the survey of weed species was carried out at the end of the cowpea cycle in both experiments. Surveys taken at different times will produce different results for the floristic composition of the weeds (LIMA et al., 2016). This is due to the dynamic nature of the emergence and disappearance of weeds in experimental areas. For example, Lima et al. (2016), carried out a survey of the number of plants of species occurring in the cowpea from 7 to 63 days after crop emergence. They found that in some species the number of plants was high at the beginning of the cycle and decreased progressively; in other species, the opposite occurred. In yet other species, the number of individuals was high at the beginning, decreased until the middle of the cycle and then increased until the end of the cycle. In addition, individuals of some species were found at each collection, but in other species, the occurrence was sporadic.

The treatments had an influence on grain yield (Table 5). The Scott-Knott test (1974) separated the varieties under evaluation grown under weed stress into three groups for grain yield (Table 6). The Umarizal, Itaú, Upanema, Lagoa de Pedras, José da Penha and São Tomé varieties stood out as superior (Table 6).

\section{Experiment-2}

There was also no effect from the treatments (Table 4) or differences between the cowpea varieties in terms of the shoot fresh and dry matter evaluated in experiment-2. Shoot fresh matter ranged from 363.0 to $679.5 \mathrm{~g} \mathrm{plant}^{-1}$, while dry matter ranged from 60.3 to $115.9 \mathrm{~g} \mathrm{plant}^{-1}$ in the José da Penha and Angicos varieties, respectively. The value for $\mathrm{CV}$ was $40.0 \%$ for both characteristics.

The treatments influenced green bean yield, determined from the green pod and green grain yield(Table 7). The response of the varieties in terms of green pod and green grain yield were different (Table 8). For both characteristics, Tukey's test identified three groups of varieties: the most productive varieties, the least productive varieties, and one group with intermediate yields. The Umarizal variety was the most productive in terms of green pod and green grain yield; this finding is interesting, as green beans are sold in the form of pods or green grain. The Baraúna, Campo Grande and Upanema varieties showed intermediate pod yields, while in the other varieties, the pod yield was lower. In terms of green grain yield, the Lagoa de Pedras, Jaçanã and José da Penha varieties had the lowest productivity, with the other varieties presenting intermediate behavior. Differences between varieties in terms of green pod and green grain yield indicate a difference in pericarp yield.

There was no difference between varieties in terms of dry grain yield, although they differed for 100-grain weight and the number of grains per pod (Table 9).

The Campo Grande and Itaú varieties had the highest grain weight, while the Baraúna and Jaçanã varieties had the highest number of grains per pod (Table 10).

As seen above, there was no difference between cowpea varieties in terms of the growth of the associated weeds (Table 5). On the other hand, there were differences between the varieties in terms of dry grain yield in experiment-1 (Table 5), and in terms of green bean (Table 7) and dry grain yield (Table 9) in experiment-2. These differences show that cowpea varieties differ in their competitive ability against weeds.

The differences between cultivars in terms of competitive ability against weeds are due to differences in the ability to access light, nutrients and water, as well as differences in allelopathic activity (WORTHINGTON et al., 2015). There

Table 7 - Summary of the analysis of variance for green pod and green bean yield and their components in traditional varieties of cowpea in experiment- $2{ }^{1}$

\begin{tabular}{|c|c|c|c|c|c|c|}
\hline \multirow{2}{*}{$\begin{array}{l}\text { Source of } \\
\text { variation }\end{array}$} & \multirow{2}{*}{$\begin{array}{l}\text { Degrees of } \\
\text { freedom }\end{array}$} & \multicolumn{5}{|c|}{ Mean square $^{1}$} \\
\hline & & $\begin{array}{l}\text { 100-grain } \\
\text { weight (g) }\end{array}$ & $\begin{array}{l}\text { Number of } \\
\text { pods per plant }\end{array}$ & $\begin{array}{l}\text { Number of } \\
\text { grains per pod }\end{array}$ & Pod yield $\left(\mathrm{kg} \mathrm{ha}^{-1}\right)$ & Green grain yield $\left(\mathrm{kg} \mathrm{ha}^{-1}\right)$ \\
\hline Blocks & 4 & $9.09^{\mathrm{ns}}$ & $17.80^{\mathrm{ns}}$ & $0.59^{\text {ns }}$ & $98,428.11^{\mathrm{ns}}$ & $159,929.98^{\mathrm{ns}}$ \\
\hline Varieties & 11 & $12.29 * *$ & $108.92 * *$ & $2.33 * *$ & $2,898,681.76^{* *}$ & $875,199.81^{*}$ \\
\hline Residual & 44 & 9.93 & 29.40 & 0.46 & $837,028.55$ & $340,055.52$ \\
\hline
\end{tabular}

1 ns; *; **: not significant, significant at $5 \%$, and significant at $1 \%$ respectively by F-test 
were no differences between the cowpea varieties in terms of shoot growth in either experiment (Table 5). Therefore, to explain the differences between the competitive abilities of the varieties under study, there remain the differences between the root systems and between allelopathic activity, neither evaluated in the experiments on which the present

Table 8 - Mean values for green pod and green grain yield and the components of green grain production in traditional varieties of cowpea in experiment-2. ${ }^{1}$

\begin{tabular}{lccccc}
\hline Traditional variety & 100-grain weight $(\mathrm{g})$ & Number of pods per plant & Pod weight $(\mathrm{kg})$ & Pod weight $(\mathrm{kg})$ & Green grain yield $(\mathrm{kg}$ ha-1 \\
\hline Umarizal & $36.5 \mathrm{bc}$ & $35.5 \mathrm{a}$ & $15.7 \mathrm{abc}$ & $5845 \mathrm{a}$ & $3476 \mathrm{a}$ \\
Baraúna & $38.1 \mathrm{bc}$ & $26.4 \mathrm{ab}$ & $16.9 \mathrm{a}$ & $4428 \mathrm{ab}$ & $2901 \mathrm{ab}$ \\
Campo Grande & $47.3 \mathrm{a}$ & $19.9 \mathrm{~b}$ & $15.6 \mathrm{abc}$ & $4504 \mathrm{ab}$ & $2586 \mathrm{ab}$ \\
Macaíba & $32.7 \mathrm{~cd}$ & $26.0 \mathrm{ab}$ & $16.1 \mathrm{ab}$ & $3751 \mathrm{~b}$ & $2579 \mathrm{ab}$ \\
São Tomé & $32.1 \mathrm{~cd}$ & $27.4 \mathrm{ab}$ & $15.8 \mathrm{abc}$ & $3763 \mathrm{~b}$ & $2523 \mathrm{ab}$ \\
Luiz Gomes & $34.7 \mathrm{bc}$ & $23.3 \mathrm{~b}$ & $15.0 \mathrm{bc}$ & $3649 \mathrm{~b}$ & $2508 \mathrm{ab}$ \\
Upanema & $35.9 \mathrm{bc}$ & $24.2 \mathrm{ab}$ & $16.1 \mathrm{abc}$ & $3939 \mathrm{ab}$ & $2507 \mathrm{ab}$ \\
Angicos & $27.7 \mathrm{~d}$ & $29.1 \mathrm{ab}$ & $16.9 \mathrm{a}$ & $3321 \mathrm{~b}$ & $2266 \mathrm{ab}$ \\
Itaú & $40.8 \mathrm{ab}$ & $19.8 \mathrm{~b}$ & $16.3 \mathrm{ab}$ & $3536 \mathrm{~b}$ & $2234 \mathrm{ab}$ \\
Lagoa de Pedras & $35.8 \mathrm{bc}$ & $23.1 \mathrm{~b}$ & $14.6 \mathrm{c}$ & $3239 \mathrm{~b}$ & $2168 \mathrm{~b}$ \\
Jaçanã & $32.0 \mathrm{~cd}$ & $23.0 \mathrm{~b}$ & $15.9 \mathrm{abc}$ & $3159 \mathrm{~b}$ & $2007 \mathrm{~b}$ \\
José da Penha & $36.7 \mathrm{bc}$ & $18.7 \mathrm{~b}$ & $15.4 \mathrm{bc}$ & $3263 \mathrm{~b}$ & $1923 \mathrm{~b}$ \\
\hline CV (\%) & 8.8 & 22.0 & 4.3 & 23.7 & 23.6 \\
\hline
\end{tabular}

${ }^{1}$ Mean values followed by the same letter within each characteristic do not differ at $5 \%$ probability by Tukey's test

Table 9 - Summary of the analysis of variance for dry grain yield and its components in traditional varieties of cowpea in experiment-2. Mossoró, RN, 2018. ${ }^{1}$

\begin{tabular}{|c|c|c|c|c|c|}
\hline \multirow{2}{*}{ Source of variation } & \multirow{2}{*}{ Degrees of freedon } & \multicolumn{4}{|c|}{ Mean square } \\
\hline & & 100-grain weight (g) & Number of pods per plant & Number of grains per pod & Grain yield $\left(\mathrm{kg} \mathrm{ha}^{-1}\right)$ \\
\hline Blocks & 4 & $0.05^{\mathrm{ns}}$ & $55.00^{\mathrm{ns}}$ & $2.59 * *$ & $147,048.18^{\mathrm{ns}}$ \\
\hline Varieties & 11 & $36.21 * *$ & $83.08^{\mathrm{ns}}$ & $6.78 * *$ & $256,836.65^{\mathrm{ns}}$ \\
\hline Residual & 44 & 1.20 & 60.53 & 0.56 & $144,743.11$ \\
\hline
\end{tabular}

$1 \mathrm{~ns} ; * ; *$ : not significant, significant at $5 \%$, and significant at $1 \%$ respectively by F-test

Table 10 - Mean values for dry grain yield and its components in traditional varieties of cowpea in experiment- $2^{1}$

\begin{tabular}{|c|c|c|c|c|}
\hline Traditional variety & 100-grain weight & Number of pods per plant & Number of grains per pod & Grain yield $\left(\mathrm{kg} \mathrm{ha}^{-1}\right)$ \\
\hline Upanema & $21.2 \mathrm{bc}$ & $26.6 \mathrm{a}$ & $16,2 \mathrm{abcd}$ & $1525 \mathrm{a}$ \\
\hline Umarizal & $20.4 \mathrm{bcd}$ & $25.8 \mathrm{a}$ & $14,6 \mathrm{~d}$ & 1388 a \\
\hline Jaçanã & $17.2 \mathrm{~g}$ & $27.7 \mathrm{a}$ & $16,8 \mathrm{ab}$ & $1386 \mathrm{a}$ \\
\hline Campo Grande & $25.0 \mathrm{a}$ & $18.5 \mathrm{a}$ & 15,8 abcd & 1356 a \\
\hline Itaú & $22.3 \mathrm{~b}$ & $18.4 \mathrm{a}$ & 16,0 abcd & $1254 \mathrm{a}$ \\
\hline Baraúna & 20.1 bcde & $18.3 \mathrm{a}$ & $17,3 \mathrm{a}$ & 1249 a \\
\hline São Tomé & $17.7 \mathrm{fg}$ & $24.4 \mathrm{a}$ & $15,6 \mathrm{bcd}$ & 1188 a \\
\hline Lagoa de Pedra & $18.7 \mathrm{defg}$ & $21.7 \mathrm{a}$ & $15,1 \mathrm{~cd}$ & $1116 \mathrm{a}$ \\
\hline Angicos & $14.4 \mathrm{~h}$ & $25.8 \mathrm{a}$ & $16,3 \mathrm{abc}$ & $1061 \mathrm{a}$ \\
\hline José da Penha & $19.3 \mathrm{cdefg}$ & $17.8 \mathrm{a}$ & $15,0 \mathrm{~cd}$ & $960 \mathrm{a}$ \\
\hline Luiz Gomes & $19.6 \mathrm{cdef}$ & $16.6 \mathrm{a}$ & $15,0 \mathrm{~cd}$ & $865 \mathrm{a}$ \\
\hline Macaíba & $17.9 \mathrm{efg}$ & $18.8 \mathrm{a}$ & $14,6 \mathrm{~d}$ & 789 a \\
\hline CV $(\%)$ & 5.2 & 35.8 & 4.8 & 32.3 \\
\hline
\end{tabular}

${ }^{1}$ Mean values followed by the same letter within each characteristic do not differ at $5 \%$ probability by Tukey's test 
study was based. However, it should be noted that there is a possibility of varieties with similar growth but with different leaf and branch architecture showing different competitiveness against weeds.

Competition between root systems generally results in less biomass than competition between the shoots of the competitors involved (KIAER et al., 2013). Furthermore, the competition between root systems is greater when one of the competitors is a grass (KIAER et al., 2013). In the present study, the most common weeds were grasses (Table 2). Another aspect that can influence crop yields, but which is generally not considered in studies of weed management, is the occurrence of pathogens and pests. The presence or absence of certain weeds can reduce the attack of certain pests (TAKIM; UDDIN II, 2010).

There were differences between the behavior of the varieties for green grain yield (Table 8) and dry grain yield (Table 10). There are three possible causes for these differences. First, there is evidence that harvesting the green pods determines a greater number of pods per plant (ALIKO et al., 2013). Second, plants grown for dry grain production spend more time in the field than those grown for green grain production, suggesting that they suffer the effects of abiotic and biotic factors (including weeds) for longer. Finally, it should be remembered that green grain and dry grain are products that are harvested and evaluated differently. For example, the ideal time for harvesting green pods is decided by the harvester, while for dry grain, the ideal time is less subjective.

\section{CONCLUSIONS}

1. In the preliminary experiment, the Umarizal, Itaú, Upanema, Lagoa de Pedras, José da Penha and São Tomé varieties were superior in terms of grain yield. The preliminary evaluation is effective in identifying superior varieties;

2. In the additional evaluation, the Umarizal variety is the most productive in terms of pod yield and green grain yield. There is no difference between the varieties for dry grain yield. The Umarizal variety has potential for the production of green pods and grains, and of dry grains.

\section{REFERENCES}

ALI, H. H. et al. Weed management using crop competition in Pakistan: A review. Crop Protection, v. 95, p. 22-30, 2017.

ALIKO, A. A. et al. Effect of harvest period on senescence and grain yield in some varieties of cowpea (Vigna unguiculata (L.) Walp). Nature and Science, v. 11, n. 10, p. 29-33, 2013.
ARRUDA, R. L. et al. Glycerine associated molecules with herbicide for controlling Adenocalymma peregrinum in cultivated pastures. African Journal of Biotechnology, v. 14, n. 45 , p. $3075-3081,2015$.

BAJWA, A. A.; WALSH, M.; CHAUAN, B. S. Weed management using crop competition in Australia. Crop Protection, v. 95, p. 8-13, 2017.

BNB. População do Nordeste atingirá 57,1 milhões em 2060. Diário Econômico ETENE, v. 1, p. 1-2, 2018.

BRAUN, H. I. The collected works of John W. Tukey. New York: Chapman and Hall, 1994. 560 p. V. VIII (Multiple comparisons: 1948-1983).

CARVALHO, F. P. et al. Alocação de matéria seca e capacidade competitiva de cultivares de milho com plantas daninhas. Planta Daninha, v. 29, n. 2, p. 373-382, 2011.

DASS, A. et al. Weed management in rice using crop competition - a review. Crop Protection, v. 95, p. 45-52, 2017.

FERREIRA, D. F. SISVAR: programa estatístico, versão 5.3 (Build 75). Lavras: Universidade Federal de Lavras, 2010.

HOCK, S. M. et al. Soybean row spacing and weed emergence time influence weed competitiveness and competitive indices. Weed Science, v. 54, n. 1, p. 38-46, 2006.

JHA, P. et al. Weed management using crop competition in the United States: A review. Crop Protection, v. 95, p. 31-37, 2017.

LIMA, R. S. et al. Levantamento fitossociológico de plantas daninhas na cultura do feijão-caupi no município de Vitória da Conquista-BA. Magistra, v. 28, n. 3/4, p. 390-402, 2016.

MEKONNEN, G. et al. Effect of planting pattern and weeding frequency on weed infestation, yield components and yield of cowpea [Vigna unguiculata (L.) Walp.] in Wollo, Northern Ethiopia. Agriculture, Forestry and Fisheries, v. 6, n. 4, p. 111-122, 2017.

METCALFE, H. et al. Designing a sampling scheme to reveal correlations between weeds and soil properties at multiple spatial scales. Weed Research, v. 56, n. 1, p. 1-13, 2016.

MFEKA, N.; MULIDZI, R. A.; LEWU, F. B. Growth and yield parameters of three cowpea (Vigna unguiculata L. Walp) lines as affected by planting date and zinc application rate. South African Journal of Science, v. 115, n. 1/2, p. 1-8, 2019.

NOGUEIRA, D. A.; PEREIRA, G. M. Desempenho de testes para homogeneidade de variâncias em delineamentos inteiramente casualizado. Sigmae, v. 2, n. 1, p. 7-22. 2013.

PEREIRA, M. R. R. et al. Herbicidas inibidores da accase em plantas de Cenchrus echinatus em estresse hídrico Bioscience Journal, v. 31, n. 1, p. 96-106, 2015.

SALIFOU, M. et al. Differential responses of 15 cowpea genotypes to three Striga hot spots in Niger. International Journal of Biological and Chemical Sciences, v. 11, n. 4, p. 1413-1423, 2017.

SANTOS, H. G. et al. Sistema Brasileiro de Classificação de Solos. 5. ed. Brasília, DF : Embrapa, 2018. 590 p. 
SCOTT, A. J.; KNOTT, M. A. A cluster analysis method for grouping means in the analysis of variance. Biometrics, v. 30, n. 3, p.507-512, 1974.

TAKIM, F. O.; UDDIN II, R. O. Effect of weed removal on insect populations and yield of Cowpea [Vigna unguiculata (L) Walp]. Australian Journal of Agricultural Engineering, v. 1, n. 5, p. 194-199, 2010.

VANDELEUR, R. K.; GILL, G. S. The impact of plant breeding on the grain yield and the competitive ability of wheat in Australia. Crop \& Pasture Science, v. 55, n. 8, p.855-861, 2004.
YADAV, T. et al. Weed management in cowpea - A review. International Journal of Current Microbiology and Applied Sciences, v. 6, n. 2, p. 1373-1385, 2017.

ZHAI, L. et al. Impact of recent breeding on the competitiveness of Chinese maize hybrids. Field Crops Research, v. 191, p.75-82, 2016.

ZYSTRO, J. P.; LEON, N.; TRACY, W. F. Analysis of traits related to weed competitiveness in sweet corn (Zea mays L.). Sustainability, v. 4, n. 3, p.543-560, 2012. 